\title{
Prevalence of Proteobacteria and Armatimonadetes phyla in a Photobioreactor under Carbon- and Nitrogen-Free Production Process
}

Patricia Tamez-Guerra ${ }^{1 *}$, Jesús 0 . Zuñiga-Sanchez ${ }^{1}$, Alonso A. Orozco-Flores ${ }^{1}$, Jose A. Valadez-Lira ${ }^{1}$, Cristina Rodriguez-Padilla ${ }^{1}$, Rosa O. CañizaresVillanueva ${ }^{2}$ and Ricardo Gomez-Flores ${ }^{1}$

${ }^{1}$ Universidad Autónoma de Nuevo León, Facultad de Ciencias Biológicas, San Nicolás de los Garza, Nuevo León, México. 66455

${ }^{2}$ Department of Biotechnology and Bioengineering, Center for Research and Advanced Studies of the National Polytechnic Institute, Instituto Politécnico Nacional, San Pedro Zacatenco, Mexico

*Corresponding author: Patricia Tamez-Guerra, Universidad Autónoma de Nuevo León, Facultad de Ciencias Biológicas, San Nicolás de los Garza Nuevo León, México, Tel: +0115281-83298-4000; E-mail: patamez@hotmail.com

Received date: March 29, 2017, Accepted date: April 25, 2017, Published date: May 02, 2017

Copyright: @ 2017 Tamez-Guerra P, et al. This is an open-access article distributed under the terms of the Creative Commons Attribution License, which permits unrestricted use, distribution, and reproduction in any medium, provided the original author and source are credited.

\begin{abstract}
In prokaryotes, the autotrophic population within the bacteria kingdom carries great biotechnological potential. For taxonomic analysis of species, the sequence encoding the small subunit ribosomal RNA gene (16S rRNA) is currently the most reliable technique for phylogenetic bacterial classification. Sequencing can define the population diversity and ecological importance within a habitat. The study of autotrophic bacteria population dynamics in a photobioreactor using a carbon- and nitrogen-free culture medium could provide information about succession dynamics under controlled conditions. The aim of this study was to identify the bacterial populations present in a photobioreactor by $16 \mathrm{~S}$ rRNA amplicon sequence comparison from samples taken at 0,7 , and 14 fermentation days. Most of the identified clones were described to the level of genera from the following phyla: Proteobacteria $(40 \%)$, Armatimonadetes $(35 \%)$, Firmicutes $(17.5 \%)$, Actinobacteria $(2.5 \%)$, and Cyanobacteria/Chloroplast $(2.5 \%)$. Bacterial strains from such phyla have been reported in aquatic environments and were considered uncultivable; however, sequences indicated the presence of the clones A-123 (ID: HQ860522.1) from time 0, and YHS25 (GU305825.1) after 7 days of culture. Our findings demonstrated the major presence of autotrophic bacterial populations of the Proteobacteria and Armatimonadetes phyla, which grew under artificial culture conditions in a photobioreactor.
\end{abstract}

Keywords: Prokaryotes; Autotroph population; Biotechnology; Bacterial adaptation; Aquatic environments

\section{Introduction}

Among aquatic microorganisms, cyanobacteria are prokaryotic cells with a wide morphological diversity including unicellular, colonial, and filamentous forms. They are distributed in terrestrial, freshwater, and saltwater, and even in extreme environments [1]. Nitrogen and phosphorus are essential nutrients for aquatic microorganism growth. Cyanobacteria grow better than other phytoplankton organisms in limiting nitrogen and/or phosphorus environmental conditions, partly due to their ability to store significant phosphorus amounts (sufficient for two to four cell divisions, increasing their biomass 4 to 32 times), and some species fix atmospheric dinitrogen [2].

Microalgae and cyanobacteria have great biotechnological potential to produce valuable substances for the food, cosmetics, and pharmaceutical industries via biotechnological processes. The physicochemical and technological bases for photobioreactors design are the most important prototrophic topics for economic success in biotechnology. For future applications, open ponds systems for large scale production possess lower innovative potential compared with the closed batch system. For high value products, and in spite of the different design approaches, a closed photobioreactor is the most promising technical system [3].

In recent years, there has been a growing interest in the metabolic properties of several enzymes and secondary metabolites produced by bacteria that have demonstrated their potential use in applied biotechnology. The bacteria kingdom represents a wide diversity of microorganisms with complex metabolism. Among autotrophic bacteria, recent highlights have demonstrated the importance of cyanobacteria due to the great biotechnological potential of their photosynthesis and dinitrogen fixation metabolic properties [4]. Based on their relationship in microbial communities with other bacteria populations, there is a need to define the taxonomy of autotrophic bacteria, using not only taxonomic criteria, but also a phylogenetic approach [5].

Traditionally, cyanobacteria have been classi ied based on morphological and ecological characteristics [6]; however, such subjective judgments can lead to errors and misidenti ication, resulting in an unreliable taxonomic assignment of isolates. Furthermore, the morphological changes induced by culture conditions and phenotypic plasticity of cyanobacteria may also lead to taxonomic identification mistakes. To address these problems, molecular markers such as $16 \mathrm{~S}$ rRNA have become reliable for strains identification.

In order to phylogenetically identify microbial populations, the use of the 16S rRNA sequence can reveal the diversity and relationship of these organisms under natural and/or artificial conditions, presenting diverse physical, chemical, and nutritional environmental habitats, where these metabolites of industrial importance are produced and released [5,7]. The study of autotrophic bacteria population dynamics in an artificial media, such as a photobioreactor, can provide information on the timing of secondary metabolites production. 
In all species above taxonomic levels, the genes encoding the smallsubunit ribosomal RNA (16S rRNA) sequence analysis is currently the most promising approach for phylogenetic cyanobacteria classification. Moreover, the comparative sequence analysis of $16 \mathrm{~S}$ rRNA genes provides the ability to investigate differences between strain collections and natural communities [8]. The $16 \mathrm{~S}$ rRNA gene sequences never change, are independent of growth conditions, and can be isolated by PCR using small amounts of extracted DNA from both laboratory cultures and natural environments [9].

Microalgae and cyanobacteria mass production cultures include existing shallow open ponds, stirred tank reactors, and tubular, column, and flat plate photobioreactors [10]. Likewise, the abundance of different bacterial populations may vary in different cultivation stages of the production process, leading to nonhomogeneous metabolite and biomass production during the cultivation course. The method described in this study is a powerful tool for investigating the phylogenetic diversity and ecological succession in a photobioreactor. This approach is particularly useful to unravel the connections between the aquatic prokaryotic microorganism populations predominant in a photobioreactor and those detected in nature, and their physiology and genetic sequence data, in addition to estimating their diversity based on operational taxonomic units (OTUs). OTUs are used to characterize species, genus or other taxonomic category. As an example of this kind of study, the only simulation of Nostocales lifecycle available models to date are based on their cellular internal nutrients [11]. The purpose of the present study was to culture an autotrophic bacterial population in a photobioreactor to provide a tool for analyzing the population succession dynamics by different species within this domain, under controlled environmental conditions.

\section{Materials and Methods}

All enzymes, substrates, and chemicals were from PROMEGA (distributed by UNIPARTS S.A., Monterrey, N.L., México), unless otherwise specified.

\section{Photobioreactor samples}

Aquatic prokaryotes were evaluated in samples from a photosynthetic microbial community isolated from a rice cultivar located at Alpuyeca municipality, in Xilotepec, Estado de Morelos, México [12]. Alpuyeca is located at $3454 \mathrm{~m}$ sea level (latitude 18.743611 and longitude -99.258056). Photobioreactor-production process using 150-L flat-face air-lift was provided by Dr. Rosa Olivia CañizaresVillanueva National Polytechnic Institute (CINVESTAV-IPN) in Mexico City. Photosynthetic microbial community biomass production was developed under controlled conditions of light and temperature, using the BG110 mineral medium [4], an inoculum percentage of $33 \%$ $(\mathrm{v} / \mathrm{v})$, and an air flow of $0.6 \mathrm{vvm}$ for 14 days.

The biomass production was developed in a closed room under controlled temperature at $21^{\circ} \mathrm{C} \pm 2^{\circ} \mathrm{C}$, and the photobioreactor was illuminated with external light source lamps (Sylvania, USA), with 80 $\mu \mathrm{mol}$ photons $/ \mathrm{m}^{2} / \mathrm{sec}$ flux, and 12:12 photoperiod $(12 \mathrm{~h} \mathrm{light} / 12 \mathrm{~h}$ darkness). Samples of $10 \mathrm{~mL}$ were collected at 0,7 , and 14 days of culture. Samples were centrifuged at 12,000 rpm (Hettich Centrifuge Universal 320R, RSU LabSupply, S.A. de C.V., Monterrey, N.L., Mexico) and supernatants were discarded. The remaining cell pellet was re-suspended in phosphate-buffer (PBS) $(137 \mathrm{mM} \mathrm{NaCl}, 2.7 \mathrm{mM}$ $\mathrm{KCl}, 10 \mathrm{mM} \mathrm{Na} \mathrm{HPO}_{4}, 1.8 \mathrm{mM} \mathrm{KH} \mathrm{PO}_{4}$, pH 7.4). DNA extraction was performed using the Multisource Genomic DNA Kit AxyPrepTM Miniprep Kit protocol (Axygen Biosciences, Union City, CA).

\section{S rRNA sequence amplification and cloning}

The total extracted and purified DNA was used for the subsequent $16 \mathrm{~S}$ rRNA sequences amplification. Oligonucleotides used for $16 \mathrm{~S}$ rRNA gene amplification were 16S rRNA Bacterial Universal primers: 27F 5'-AGAGTTTGATCMTGGCTCAG-3' and 1492R 5'GGYTACCTTGTTACGACTT-3') reported by Zehr et al. [13]. For the PCR reaction, $200 \mathrm{ng}$ of total DNA from each sample (3 time periods, 3 replicate determinations per time period) were processed using the Taq \& GoTM Master Mix 5X and 1- $\mu \mathrm{M}$ of each oligonucleotide. Samples of $30 \mu \mathrm{l}$ were prepared using $6 \mu \mathrm{l} \mathrm{Taq} \&$ GoTM Master Mix, $3 \mu \mathrm{l}$ of 27F primer, $3 \mu \mathrm{l}$ of $1492 \mathrm{R}$ primer, $4 \mu \mathrm{l} \mathrm{DNA}$, and $4 \mu \mathrm{l}$ milliQ water. PCR reaction conditions were of an initial denaturation at $94^{\circ} \mathrm{C}$ for $10 \mathrm{~min}$, followed by 35 amplification cycles, 1-min denaturation step at $94^{\circ} \mathrm{C}$, annealing at $54^{\circ} \mathrm{C}$ for $1 \mathrm{~min}$, extension at $72^{\circ} \mathrm{C}$ for $1 \mathrm{~min}$, and final extension cycle at $72^{\circ} \mathrm{C}$ for $10 \mathrm{~min}$, using a Gradient Thermal Cycler (Model Axygen Brand: Maxygene Gradient, Catalog: THERM-1001; PROLAB, S.A. de C.V., Mexico City, Mexico) [12].

For PCR product cloning and sequencing, samples were purified following the Wizard ${ }^{\circ}$ SV Gel and PCR Clean-Up System kit protocol. The purified band was inserted into a pGEM-T Easy plasmid using a 1:1 molar ratio of the insert DNA to the vector.

In order to select the $E$. coli clones with the plasmid insert, transformed cells were grown by expansion on LB agar with $100 \mu \mathrm{g} / \mathrm{ml}$ ampicillin, in addition to $0.5 \mathrm{mM}$ isopropyl- $\beta$ - D-1thiogalactopyranoside (IPTG) as LacZ gene inducer, and $80 \mu \mathrm{g} / \mathrm{mL} 5$ bromo-4-chloro-3-indolyl- $\beta$-D-galactosidase (X-gal) as insert control, to become degraded by $\beta$-galactosidase and stained in blue those colonies lacking the insert.

All white colonies of each of the photobioreactor collected samples from different time periods were selected to analyze the specific transcripts amplification by using a "colony PCR" to confirm the presence of the target product. For this, the $\mathrm{pUC} / \mathrm{M} 13$ vector, where the $16 \mathrm{~S}$ rRNA insertion was expected, was amplified. Each potential "colony PCR" was cut with a lace and inoculated for a PCR reaction in $200 \mu \mathrm{l}$ Eppendorf tubes; each reaction was prepared with $5 \mu \mathrm{l} \mathrm{Taq}$ Master Mix \& GoTM (5X), $1 \mathrm{nM}$ of either M13F or M13R primers. he reaction was adjusted to a final volume of $10 \mu \mathrm{l}$ with nuclease-free water. In the resulting blue colonies, the lack of the target plasmid was assumed.

The oligonucleotide sets for the M13 region amplification were
M13F 5'-GTTTTCCCAGTCACGAC-3' and M13R 5'CAGGAAACAGCTATGAC-3'.

The reaction conditions were the following: an initial cycle of denaturation at $94^{\circ} \mathrm{C}$ for $15 \mathrm{~min}$, followed by 30 amplification cycles, denaturation at $94^{\circ} \mathrm{C}$ for $40 \mathrm{sec}$, annealing at $49^{\circ} \mathrm{C}$ for $40 \mathrm{sec}$, extension at $72^{\circ} \mathrm{C}$ for $2 \mathrm{~min}$, and a final extension cycle at $72^{\circ} \mathrm{C}$ for $10 \mathrm{~min}$.

Detected PCR products were further purified to quantify their concentration and to perform the ligation reaction. Each purified product was inserted into the pGEM-T easy vector for subsequent cloning in transformed TOP $10 \mathrm{E}$. coli competent calcium strain and cultured in antibiotic-added medium (LB agar with ampicillin at 100 $\mu \mathrm{g} / \mathrm{ml})$. White colonies with the insert were cultured in $10 \mathrm{ml}$ of $\mathrm{LB}$ medium for $12 \mathrm{~h}$ : subsequently the plasmid was extracted by the indicated kit (Corning Axygen ${ }^{\circ}$ AP-MN-P250 AxyPrep ${ }^{\text {mm }}$ Plasmid DNA 
Citation: Tamez-Guerra P, Zuñiga-Sanchez OJ, Orozco-Flores AA, et al., (2017) Prevalence of Proteobacteria and Armatimonadetes phyla in a Photobioreactor under Carbon- and Nitrogen-Free Production Process. Ferment Technol 6: 142. doi:10.4172/2167-7972.1000142

Page 3 of 8

Purification Miniprep) (Axygen). In order to confirm the amplicon presence, each sample was cultured and DNA was extracted to amplify the M13 region (250 bp size) from the pGEM-T Easy vector, where the selected 16S rRNA sequence region (about $1500 \mathrm{bp}$ ) was expected. In addition to EcoRI to each ligation site ends, the plasmid also contained multiple restriction sites, so that enzymatic digestion was performed by EcoRI to release the plasmid insert and to confirm its presence by electrophoresis on $1 \%$ agarose gel.

For diversity analysis, purified plasmids were sent to the National Laboratory of Genomics for sequencing. Samples of $20 \mu \mathrm{L}$ with 100 $\mathrm{ng} / \mu \mathrm{l}$ homogeneous concentration were sent in 96 well plates per sampling time. Sequencing was performed by using the Sanger method [14] with some modifications, using M13 bidirectional universal primers [15]. To identify the genus and/or species in the microbial populations, 16S rRNA sequences were compared and analyzed with those reported in the National Center for Biotechnology Information http://www.ncbi.nlm.nih.gov/ and The Ribosomal Database Project http://rdp.cme.msu.edu/. Forward and reverse sequences were assembled and edited for a consensus sequence and discard errors by Geneious (Biomatters Limited, Auckland, New Zealand) version 4.8.5 software. The consensus sequences were compared with $16 \mathrm{~S}$ ribosomal RNA sequences databases using Basic Local Alignment Search Tool (BLAST) of the National Center for Biotechnology Information (NCBI). The sequences with the highest similarity were downloaded in FASTA format to be used as reference in phylogenetic analyzes.

\section{Phylogenetic analysis}

The taxonomic classification was performed using the Ribosomal Database Project tools http://rdp.cme.msu.edu/ [16]. Each file in FASTA format was introduced to this web site with all the obtained clone sequences for analysis and classification. Consensus sequences were aligned with ClustalW computational algorithms [17]. Phylogenetic trees based on the evolutionary history of $16 \mathrm{~S}$ rRNA were performed in MEGA 6 free software [18], using the neighbor joining method with a 1500 replica bootstrap test, assuming uniform heterogeneity among sites. Based on the substitutions per site number, all positions with gaps and missing data were discarded.

\section{Results}

\section{Biomass production}

Biomass production in fermentation tanks showed an adaptation phase of $7 \mathrm{~d}$, resulting in a biomass reduction of $5 \%$. Because of this, 7 days were selected for sampling. The fermentation process was stopped after $14 \mathrm{~d}$ because no further biomass production was observed, and samples were collected. Once all biomass was collected, dried, and weighed, the total yield was $0.305 \mathrm{~g} / \mathrm{L}( \pm 0.01)$.

\section{Bacterial 16S rRNA sequence from the microbial community}

Each $16 \mathrm{~S}$ ribosomal small-subunit sequence from PCR amplification of DNA of the time-course samples was analyzed. A PCR product of approximately 1500 bp was obtained, which was the expected size for this sequence amplification (Figure S1).

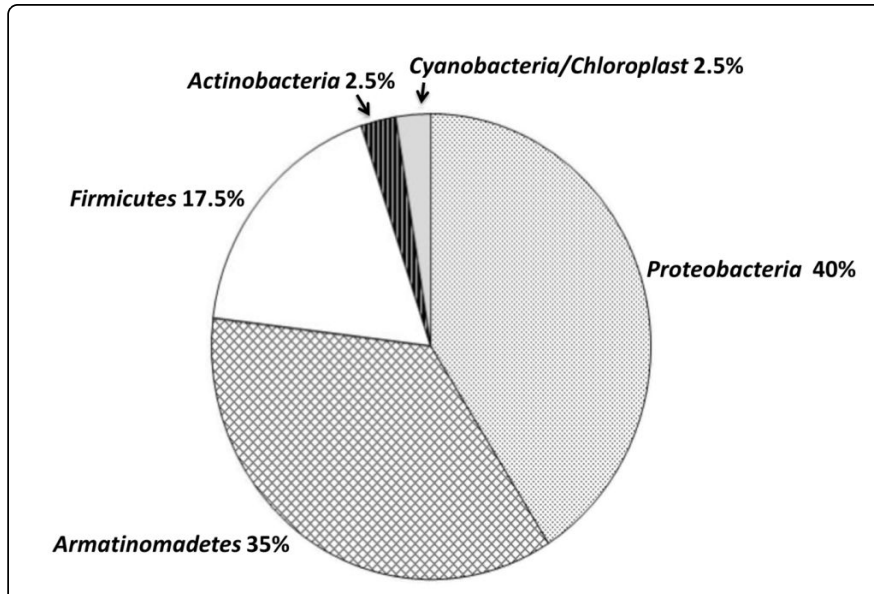

Figure 1: Operational taxonomic units analysis revealing Proteobacteria, Armatimonadetes, Firmicutes, Actinobacteria, and Cyanobacteria/Chloroplast phyla based on the 16S rRNA gene library.

The purified PCR products inserted into the pGEM-T easy vector confirmed the amplicon presence, where the selected 16S rRNA sequence region (about 1500bp) was as expected. A product of the predicted size (1750bp) was obtained (Figure S2). The inserted 16S gene inside pGEMT, after EcoRI characterization was visualized in a $1 \%$ agarose gel (Figure $\mathrm{S} 3$ ).

DNA cloned products from all selected colonies were sequenced and analyzed using the NCBI database. One clone was identified as uncultured bacterium clone A-123 (ID: HQ860522.1), which was present in the samples of the initial time ( 0 day), whereas at $7 \mathrm{~d}$ the most frequently detected clone was identified as uncultured bacterium clone YHS25 (GU305825.1). In fact, these two clones (A-123 and YHS25) were commonly detected at 0 and $7 \mathrm{~d}$ from the time-course samples.

Of the 41 clones sequenced and analyzed using the Ribosomal Database Project, the clones marked with 13, 21, and 39 numbers did not show a consistent taxonomic classification after using NCBI information with BLAST, and were classified as phylum Proteobacteria, class Alphaproteobacteria (clone 13); phylum Actinobacteria, class Actinobacteria (clone 21); and Bacteria kingdom as environment bacterioplankton sample (clone 39).

\section{Bacterial phylogenetic identification}

Based on the 16S rRNA sequences, most of the clones were identified to genus level comparing sequences in the Ribosomal Database Project web site (http://rdp.cme.msu.edu). There were six different related genera sequences (Table 1). Furthermore, one clone marked as 27 also resulted as "no significant similarity" in any analysis and was discarded.

Out of all the sequenced clones, six different OTUs were detected, where the largest portion of the 16S rRNA gene library phyla belonged to Proteobacteria (40\%) and Armatimonadetes (35\%), followed by Firmicutes (17.5\%). 
Citation: Tamez-Guerra P, Zuñiga-Sanchez OJ, Orozco-Flores AA, et al., (2017) Prevalence of Proteobacteria and Armatimonadetes phyla in a Photobioreactor under Carbon- and Nitrogen-Free Production Process. Ferment Technol 6: 142. doi:10.4172/2167-7972.1000142

Page 4 of 8

\begin{tabular}{|c|c|c|c|}
\hline Sampling time (days)/ Clone identification number & $\begin{array}{l}\text { Genebank } \\
\text { reference }\end{array}$ & References & Similarity (\%) \\
\hline \multicolumn{4}{|c|}{0} \\
\hline Pseudomonas sp. H9zhy strain H9zhy (42) & AM410625.1 & Kandel et al., & 99 \\
\hline Rhodobacter sp. TCRI 14 (47) & AB017799.1 & Inui et al., & 96 \\
\hline Uncultured bacterium clone YHS25 (43) & GU305825.1 & Jaramillo-Lambert et al., & 93 \\
\hline Uncultured bacterium clone A-1231 $(44,45)$ & HQ860522.1 & Bai et al., & 89,94 \\
\hline Uncultured bacterium clone EDW07B006_1 (48) & HM066641.1 & Gray \& Engel, & 93 \\
\hline \multicolumn{4}{|c|}{7} \\
\hline Pseudomonas sp. H9zhy strain H9zhy (36) & AM410625.1 & Kandel et al., & 96 \\
\hline Uncultured Brevundimonas sp. clone A05-G1409301364-1-14-M13F(-47) (37) & KP406373.1 & Li et al., & 93 \\
\hline Uncultured bacterium clone A-123 (39) & HQ860522.1 & Bai et al., & 84 \\
\hline Uncultured bacterium clone E65 (35) & KC683282.1 & Zhou et al., & 94 \\
\hline Uncultured bacterium clone RS-F40 (40) & KC541420.1 & Li \& Sun unpublished & 74 \\
\hline Uncultured bacterium clone YHS251 $(38,41)$ & GU305825.1 & Jaramillo-Lambert et al., & 88,98 \\
\hline \multicolumn{4}{|c|}{14} \\
\hline Exiguobacterium sp. 3045 (4) & JX566576.1 & Huang et al., & 96 \\
\hline Exiguobacterium sp. 4091 (28) & JX566608.1 & Huang et al., & 97 \\
\hline Exiguobacterium acetylicum strain DCH-3 (17) & KC166866.1 & Wang et al., & 78 \\
\hline Exiguobacterium acetylicum strain NBRC 12146 (10) & NR_113585.1 & Muramatsu et al., & 87 \\
\hline Nodosilinea nodulosa UTEX 2910 (11) & KF307598.1 & Muehlsteinova et al., & 97 \\
\hline Pseudomonas sp. clone AUTH 28 (18) & FR725962.1 & Karamanoli et al., & 93 \\
\hline Pseudomonas sp. IBUN N2103 (24) & DQ813322.1 & Revelo-Romo et al., & 81 \\
\hline Uncultured Actinobacterium isolate ARBAF18A86D (29) & LC018951.1 & Bižić-lonescu et al., & 89 \\
\hline Uncultured Actinobacterium isolate ARBA920CE6D (21) & LC018947.1 & Bižić-Ionescu et al., & 89 \\
\hline Uncultured Alpha Proteobacterium clone B10-3 (13) & FN594640.1 & Tomczyk-Żak et al., & 79 \\
\hline Uncultured bacterium clone A-1232 $(5,7,22,32)$ & HQ860522.1 & Bai et al., & $92-97$ \\
\hline Uncultured bacterium clone BF5_0837 (16) & KC307518.1 & Umani \& Beran, & 90 \\
\hline Uncultured bacterium clone E65 (23) & KC683282.1 & Zhou et al., & 84 \\
\hline Uncultured bacterium clone EDW07B001_102 (12) & HM066311.1 & Gray \& Engel, & 94 \\
\hline Uncultured bacterium clone EDW07B003_80 (8) & HM066478.1 & Gray \& Engel, & 83 \\
\hline Uncultured bacterium clone J304-47 (1) & KM823773.1 & Zeng et al., & 96 \\
\hline Uncultured bacterium clone RS-B13 (2) & KC541067.1 & $\begin{array}{l}\text { Li \& Sun, unpublished } \\
\text { Stevens et al., }\end{array}$ & 90 \\
\hline Uncultured bacterium clone SF8B38 (31) & JX680801.1 & Lu et al., & 87 \\
\hline Uncultured bacterium clone SZS'-0_96 (30) & HM049711.1 & Jaramillo-Lambert et al., & 95 \\
\hline
\end{tabular}


Citation: Tamez-Guerra P, Zuñiga-Sanchez OJ, Orozco-Flores AA, et al., (2017) Prevalence of Proteobacteria and Armatimonadetes phyla in a Photobioreactor under Carbon- and Nitrogen-Free Production Process. Ferment Technol 6: 142. doi:10.4172/2167-7972.1000142

Page 5 of 8

Table 1: BLAST closest matches to excised and sequenced $16 \mathrm{~S}$ rRNA, compared with reported NCBI sequences.

In contrast, Actinobacteria and Cyanobacteria/Chloroplast were found in the smallest portion of the 16S rRNA gene library phyla (2.5\%) (Figure 1).

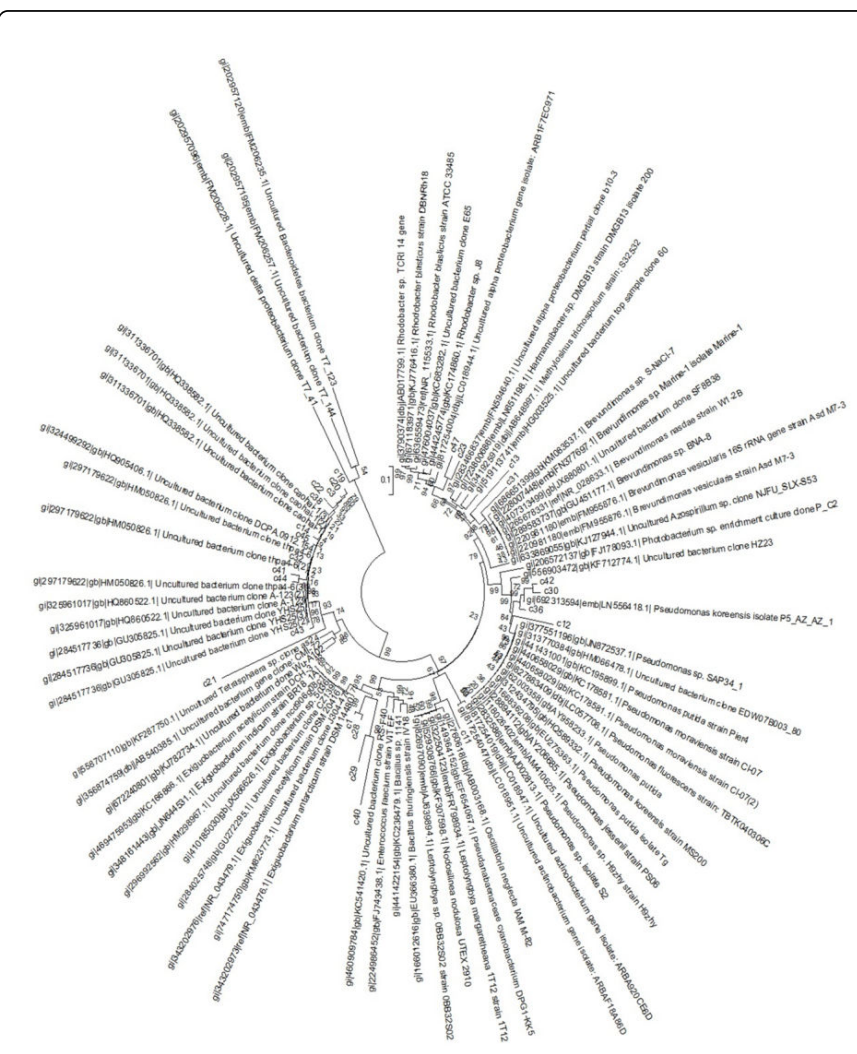

Figure 2: Phylogenetic tree of bacterial community results from the $16 \mathrm{~S}$ rRNA sequences analysis obtained from a photoreactor timecourse samples. Only those isolates marked with an asterisk belong to the Cyanobacteria/Chloroplast phylum.

Phylogenetic analysis resulted in a total of 1,506 positions in the last set of data. The analysis was based on 95 DNA sequences where all gaps and erroneous sequences were eliminated. The phylogenetic tree was obtained with optimum amount of 5.28 branches (Figure 2).

\begin{tabular}{|c|c|}
\hline $\begin{array}{c}\text { Phylum (number of detected } \\
\text { sequences) }\end{array}$ & $\begin{array}{c}\text { Clones classification (number of } \\
\text { detected sequences) }\end{array}$ \\
\hline \multirow{6}{*}{ Proteobacteria } & " » » class Proteobacteria \\
\hline & " $\gg » "$ order \\
\hline & " " » » " family \\
\hline & » " " " \\
\hline & » » " » order Rhodobacter \\
\hline & » » » » » family Rhodobacter \\
\hline
\end{tabular}

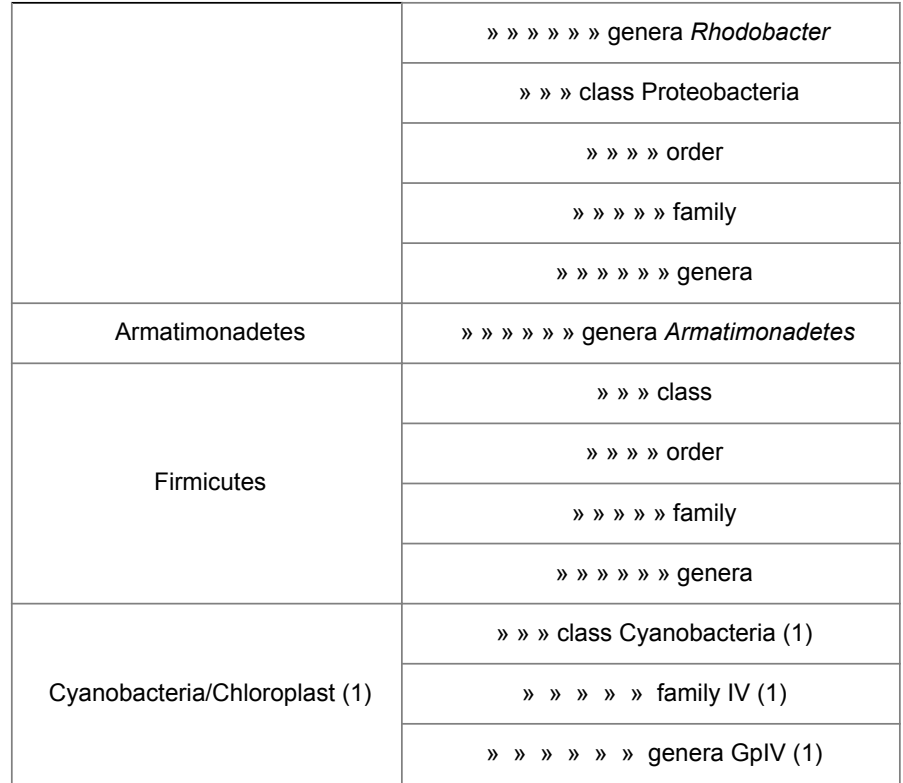

Table 2: Genus level clones identification based on the Ribosomal Database Project.

\section{Discussion}

In order to determine the bacterial genera diversity, the OTU analysis was used. Contrary to what was expected, detected OTUs did not belong to the Cyanobacteria phylum (Tables 1 and 2). The reasons why different cyanobacteria/chloroplast phyla may be present is explained by Peleato-Sánchez [7], who indicated that like other prokaryotes, cyanobacteria communicate with other individuals in the population and send molecular messages to the external environment inhabitants present within the same habitat. The cells produce, excrete, and detect molecules named auto-inducers at high concentrations, prompting cyanobacteria to enter in a new physiological status by specific gene expression, which is characterized by a collective response that adopt all cells population.

In the present study, in order to identify the bacterial population in the time course culture in a photobioreactor by phylogenetic analysis, we expected to find one bacteria phylum, Cyanobacteria/Chloroplast. However, the results showed a highly variable bacterial population in the analyzed samples (Table 1). This may be due to bacterial interactions initiated in the collected water sample. A similar report published by Tsubouchi et al. [19] showed that Brevundimonas sp., identified by $16 \mathrm{~S}$ phylogenetic analysis, was isolated from a marine sediment environment; they stated that these bacteria are particularly widespread in the aquatic realm, which supports our results.

Similarly, Jerônimo-Lima et al. [20] detected the heterotrophic bacteria Rhodobacter sp., strain CACIA $14 \mathrm{H1}$, from total DNA extracted from a non-axenic culture of the cyanobacteria Cyanobium sp., strain CACIA 14, isolated from fresh water of a hydroelectric dam in Brazil; they discussed that cyanobacteria require the presence of 
aerobic heterotrophic bacteria for their growth, probably because this community is an integral part, along with the cyanobacteria community, within the aquatic ecosystem habitat, as they have importance in the denitrification process where nitrogen is produced. Cyanobacteria have specialized cells called heterocyst involved in dinitrogen fixation by the nitrogenase enzyme, which reduces and uses it as an ammonium subproduct [7]. It has been reported that microalgae can develop synergies with heterotrophic bacteria in relation to the carbon cycle, decreasing the need for external $\mathrm{O}_{2}$ supply [21]. In addition, microalgae are primary carbon dioxide producers after synthesizing organic compounds, thus supporting heterotrophic organisms (consumers) that decompose and recycle organic compounds.

In our results, clones previously reported in microbial communities along with cyanobacteria were identified, including the heterotrophic bacteria Pseudomonas [22], Brevundimonas, and Rhodobacter [20], supporting our assumption of their initial interaction as a consortium from the water source. Li et al. [23] developed a metagenomics study on microorganisms associated with the Microcystis aeruginosa cyanobacterium, using the pyrosequencing method, indicating the predominant presence of Alphaproteobacteria, Betaproteobacteria and Gammaproteobacteria classes, demonstrating the extraordinary diversity of microbial community within an ectosymbiotic system. However, to date there exists scarce information on microbial communities associated with cyanobacteria and interactions between these organisms. In the present study, Proteobacteria was shown as the main bacterial group of the Alphaproteobacteria and Gammaproteobacteria classes.

As for the clones identified within the Armatimonadetes phylum, Lee et al. [24] reported the uncultured strains Armatimonas rosea and Chthonomonas calidirosea, isolated from aquatic habitats and wastewater [25]. Similarly, the second predominant group found in this study was the Armatimonadetes (OP-10); one of the reasons why its identification to genus differed from the two strains mentioned above, may be related to the poorly defined Armatimonadetes phylogenetic relationship with other bacterial phyla, due to the limited number of cultivable strains [24]. Therefore, phylogenetic analysis of this order is largely limited to the $16 \mathrm{~S}$ rRNA gene sequence.

Strains identified within the genus Exiguobacterium have been previously reported as bacteria in microbial consortium with phytoplankton communities living in stratified lakes. In this regard, Messyasz et al. [26] reported that the main group of phytoplankton bacteria is associated with Exiguobacterium genus members, which may be also present within the same sample of water used in the photobioreactor. After comparing with the NCBI database, all sequences obtained from each of the time periods were different bacteria than the expected Cyanobacteria/Chloroplast; however, most of the identified clones were related to isolates reported from aquatic environments, like the samples used in our study. Salomon et al. [27] reported that colonial and filamentous cyanobacteria commonly associate with bacteria on their extracellular mucus area or they are strongly attached to their cells surface, providing the microenvironment for the particular microbiome development. In a previous study, 13 bacterial strains associated with Nodularia spumigena filament growing in the Baltic Sea, were isolated and identified within the Gram-positive bacteria division by the $16 \mathrm{~S}$ rRNA gene sequencing. Results showed different bacterial lineages associated with the cyanobacterial filament, including Alpha-, Beta-, and Gamma-proteobacteria class and Firmicutes phylum [27]. Our results indicated that clones were related to bacterial isolates from different aquatic ecosystems; the report of Pamplona-Silva et al. [5] described the nutritional strategies and metabolic diversity potential of Cyanobacteria to colonize terrestrial and extreme environments. Most of the detected clones showed similarity to non-cultivable strain isolated from aquatic environments, therefore these could be cyanobacterial strains that have not yet been properly identified and/or reported. A pair of clones was placed within the unculturable Actinobacteria phylum, present in the same water where sample was collected. This may be related to the fact that Actinobacteria use the cyanobacteria biomass as growth promoter, and both concur in the same water environment [23]. The Protobacteria, particularly of the Alphaproteobacteria and Betaproteobacteria classes, and Actinobacteria, are abundant in freshwater habitats but are relatively difficult to grow [26]. Out of the clones sequences from samples collected in the first culture time (0 days), 66\% had similar DNA sequence to unculturable bacteria, whereas 7 and $14 \mathrm{~d}$ samples showed up to $85 \%$ and $74 \%$ similarity, respectively.

The primers used for amplification of 16S rRNA gene sequence reported by Zher et al. [13] were selected in this study, and resulted in 29 amplified sequences identified as Alphaproteobacteria class members, and more than 50 sequences were classified as other bacteria.

After studying cyanobacterial communities in Brazilian mangrove ecosystems using dependent farming methods, Pamplona-Silva et al. [5] classified five isolates within the cyanobacteria Pseudanabaenaceae family, similar to Leptolyngbya genus, one within the Nodosilinea genus (which was one of our findings from the GenBank database) emphasizing that this genus was recently described Leptolyngbya as a separate phylogenetic lineage, but they shared characteristics such as formation of nodules and a common diacritical morphological character that can be observed under low light conditions. This supports the explanation of why in the phylogenetic tree (Figure 2), the analysis showed that one of the clones was related not only as a cyanobacterium of Pseudanabaenaceae family, but was also related to the two afore mentioned genera. However, identification based on GenBank showed that this strain had a higher similarity to Nodosilinea genera (Table 1), which is classified under the Oscillatoriales subsection III [28].

The presence of different bacteria to this phylum in the databases revealed the association of microalgae (eukaryotic) and cyanobacteria with other aerobic and anaerobic microorganisms that could have adapted to the growing conditions in the artificial environment [10]. We did not test any eukaryotic gene oligonucleotide in this study. In a similar study testing a microbial community from the same area, where population showed high capacity for nitrogen fixation (based on acetylene reduction), 21 microorganisms were characterized, including nine eukaryotic microalgae, two Chlorophyta and seven Heterokontophyta [12]. Even though in our study we were able to identify 41 bacteria, only two, Rhodobacter sp. and Alpha proteobacteria, were fully identified as belonging to a well-recognized genera. We detected many unculturable bacteria, similar to Hernández-Melchor report [12]. Based on their results, we believe that eukaryotic microalga were growing during the fermentation process as well. Subashchandrabose et al. [29] reported that algae cultures in the laboratory have maintained a symbiotic relationship with bacteria. Certain bacteria associate with microalgae, even under laboratory culture conditions, as unialgal crops. However, the number of isolates from specific genera was higher than others (Table 1), and the different 
Citation: Tamez-Guerra P, Zuñiga-Sanchez OJ, Orozco-Flores AA, et al., (2017) Prevalence of Proteobacteria and Armatimonadetes phyla in a Photobioreactor under Carbon- and Nitrogen-Free Production Process. Ferment Technol 6: 142. doi:10.4172/2167-7972.1000142

Page 7 of 8

number of isolates obtained may be due to their ubiquity or the fact that they were easier to amplify by the selected primer.

In this study, a microbial consortium was cultured in carbon- and nitrogen-free medium. Out of the identified bacteria, Nodosilinea nodosa considered as pseudanabaena (Cyanobacteria), and Rhodobacter sp., are photosynthetic and dinitrogen fixing bacteria, which explains the growth of the consortium [5,28-31].

In an effort to rearrange the phylogenetic relationships of "The Tree of Life", represented by sequenced genomes based on the ribosomal protein tree compared with the SSU rRNA gene tree, Hug et al. [32] classified "Cyanobacteria" as one well-defined branch separate from the "Melainabacteria" branch, both linked with RBX1 and WOR 1 branches. This "ribosomal protein tree" includes organisms with incomplete or unavailable SSU rRNA gene sequences. Based on this ribosomal protein classification, it is important to determine if the unclassified isolates detected in this study, belong to the Cyanobacteria phylum.

Taken together, our results demonstrated that the bacterial species diversity identified as Proteobacteria and Armatimonadetes phyla were the predominate population in an autotrophic production process, using a nitrogen-free medium photobioreactor, rather than the expected Cyanobacteria/Chloroplast phylum. Metabolic analysis may help associating each population activity inside the microbial community to relate this system productivity and feasibility to be used as biofertilizer.

\section{Acknowledgments}

This study was supported by Laboratorio de Inmunología y Virología (FCB-UANL), Departamento de Biotecnología y Bioingeniería (CIVESTAV-IPN), and PAICYT-UANL grant No. CT294-15 to PTG.

\section{References}

1. Pineda-Mendoza R, Martínez-Jerónimo F, Garduño-Solórzano G, OlveraRamírez R (2011) Caracterización morfológica y molecular de cianobacterias filamentosas aisladas de florecimientos de tres lagos urbanos eutróficos de la ciudad de México. Polibotánica 31: 31-50.

2. Kaebernick M, Neilan BA (2001) Ecological and molecular investigations of cyanotoxin production. FEMS Microbiol Ecol 35: 1-9.

3. Pulz O (2001) Photobioreactors: production systems for phototrophic microorganisms. Appl Microbiol Biotechnol 57: 287-293.

4. Rippka R, Deruelles J, Waterbury JB, Herdman M, Stanier RY (1979) Generic assignments, strain histories and properties of pure cultures of cyanobacteria. Microbiol 111: 1-61.

5. Pamplona-Silva CS, Bonaldo-Genuário D, Vieira-Vaz MG, Fátima-Fiore M (2014) Phylogeny of culturable cyanobacteria from Brazilian mangroves. Syst Appl Microbiol 37: 100-112.

6. Casamatta DA, Johansen JR, Vis ML, Broadwater ST (2005) Molecular and morphological characterization of ten polar and near-polar strains within the Oscillatoriales (Cyanobacteria). J Phycol 41: 421-438.

7. Peleato-Sánchez ML (2011) Las Cianobacterias: Cooperación versus Competencia. Real Academia de Ciencias Exactas, Físicas, Químicas de Zaragoza. Universidad de Zaragoza, España, 2011, 42 p.

8. Honda D, Yokota A, Sugiyama J (1999) Detection of seven major evolutionary lineages in cyanobacteria based on the 16S rRNA gene sequence analysis with new sequences of five marine Synechococcus strains. J Mol Evol 48: 723-739.

9. Giovannoni SJ, Turner S, Olsen GJ, Barns S, Lane DJ, et al., (1988) Evolutionary relationships among cyanobacteria and green chloroplasts. J Bacteriol 170: 3584-3592.
10. Lakaniemi AM, Intihar VM, Tuovinen OH, Puhakka JA (2012) Growth of Chlorella vulgaris and associated bacteria in photobioreactors. Microbial Biotechnol 5: 69-78.

11. Jöhnk KD, Brüggemann R, Rücker J, Luther B, Simon U, et al., (2011) Modelling life cycle and population dynamics of Nostocales (cyanobacteria). Env Modell Software 26: 669-677.

12. Hernández-Melchor DJ, Carmona-Jiménez J, Hidalgo-Lara ME, Dendooven L, Marsh-Moreno R, et al., (2016) Identificación morfológica y filogenética de un consorcio microbiano fotosintético de posible interés biotecnológico. Hidrobiol 26: 311-321.

13. Zehr J, Bench S, Carter B, Hewson I, Niazi F, et al., (2008) Globally distributed uncultivated oceanic $\mathrm{N}_{2}$-fixing cyanobacteria lack oxygenic photosystem II. Science 322: 1110-1112.

14. Sanger F, Coulson AR (1975) A rapid method for determining sequences in DNA by primed synthesis with DNA polymerase. J Mol Biol 94: 441-446.

15. Woese C, Sogin M, Stahl D, Lewis BJ, Bonen L (1977) A comparison of the 16S ribosomal RNAs from mesophilic and thermophilic bacilli: some modifications in the Sanger method for RNA sequencing. J Mol Evol 7: 197-213.

16. Cole JR, Wang Q, Cardenas E, Fish J, Chai B, et al. (2008) The ribosomal database project: improved alignments and new tools for rRNA analysis. Nucleic Acids Res 37: D141-145 (Database issue).

17. Edgar RC (2004) MUSCLE: multiple sequence alignment with high accuracy and high throughput. Nucleic Acids Res 32: 1792-1797.

18. Tamura K, Stecher G, Peterson D, Filipski A, Kumar S (2013) MEGA6: Molecular evolutionary genetics analysis version 6.0. Mol Biol Evol 30: 2725-2729.

19. Tsubouchi T, Shimane Y, Usui K, Shimamura S, Mori K, et al. (2013) Brevundimonas abyssalis sp nov, a dimorphic prosthecate bacterium isolated from deep-subsea floor sediment. Int J Sys Evol Micr 63: 1987-1994.

20. Jerônimo-Lima AR, Santos-Siqueira A, Garcia-Simões dos Santos B, Florêncio da Silva FD, Toshio-Inada D, et al. (2014) Draft genome sequence of Rhodobacter sp. strain CACIA 14H1, a heterotrophic bacterium obtained from a nonaxenic culture of a Cyanobium species. Genome Announc 2: 1-2.

21. Babatsouli P, Fodelianakis S, Paranychianakis N, Venieri D, Dialynas M (2015) Single stage treatment of saline wastewater with marine bacterialmicroalgae consortia in a fixed-bed photobioreactor. J Hazard Mater 292: 155-163.

22. Llenque-Díaz LA (2011) Aislamiento e identificación de bacterias heterótrofas de suelos contaminados con petróleo provenientes de oleocentros de la ciudad de Trujillo, Perú. Re Biol 31: 1-7.

23. Li N, Zhang L, Li F, Wang Y, Zhu Y, et al., (2011) Metagenome of microorganisms associated with the toxic Cyanobacteria Microcystis aeruginosa analyzed using the 454 sequencing platform. Chinese Oceanol Limnol 29: 505-513.

24. Lee KCY, Dunfield PF, Stott MB (2014) The Phylum Armatimonadetes, Springer-Verlag Berlin Heidelberg. 1: 447-458.

25. Tamaki H, Tanaka Y, Matsuzawa H, Muramatsu M, Meng XY, et al ., (2010) Armatimonas rosea gen. nov., sp. nov., a Gram-negative, aerobic, chemoheterotrophic bacterium of a novel bacterial phylum, Armatimonadetes phyl. nov., formally called the Candidate phylum OP10". Int J Sys Evol Micr 61: 1442-1447.

26. Messyasz B, Gabka M, Barylski J, Nowicki G, Lamentowicz Ł, et al. (2015) Phytoplankton, culturable bacteria and their relationships along environmental gradients in a stratified eutrophic lake. Carpath J Earth Env. 10: 41-52.

27. Salomon PS, Janson S, Granéli E (2003) Molecular identification of bacteria associated with filaments of Nodularia spumigena and their effect on the cyanobacterial growth. Harmful Algae 2: 261-272.

28. Perkerson RP III, Johansen JR, Kovácik L, Brand J, Kas`tovsky' J, Casamatta DA (2011) A unique pseudanabaenalean (Cyanobacteria) genus Nodosilinea Gen. Nov. based on morphological and molecular data. J Phycol 47: 1397-1412. 
Citation: Tamez-Guerra P, Zuñiga-Sanchez OJ, Orozco-Flores AA, et al., (2017) Prevalence of Proteobacteria and Armatimonadetes phyla in a Photobioreactor under Carbon- and Nitrogen-Free Production Process. Ferment Technol 6: 142. doi:10.4172/2167-7972.1000142

Page 8 of 8

29. Subashchandrabose SR, Ramakrishnan B, Megharaj M, Venkateswarlu K, Naidu R (2011) Consortia of cyanobacteria/microalgae and bacteria: Biotechnological potential. Biotechnol Adv 29: 896-907.

30. Inui M, Nakata K, Roh JH, Vertès AA, Yukawa H (2003) Isolation and molecular characterization of pMG160, a mobilizable cryptic plasmid from Rhodobacter blasticus. Appl Environ Microbiol 69: 725-733.

31. Muehlsteinova R, Johansen JR, Pietrasiak N, Martin MP, Osorio-Santos K (2014) Polyphasic characterization of Trichocoleus desertorum
(Pseudanabaenales, Cyanobacteria) from desert soils and phylogenetic placement of the genus Trichocoleus. Phytotaxa 163: 241-261.

32. Hug LA, Baker BJ, Anantharaman K, Brown CT, Probst AJ, et al. (2016) A new view of the tree of life. Nature Microbiol 1: 16048. 